\title{
HUBUNGAN FAKTOR IKLIM DENGAN KASUS DBD DI KOTA BANDAR LAMPUNG TAHUN 2015 - 2019
}

\author{
Gilang Fitra Dininta ${ }^{{ }^{*}}$, Dessy Hermawan ${ }^{2}$, Ringgo Alfarisi ${ }^{3}$, Achmad Farich ${ }^{4}$ \\ 1,2,3,4 Fakultas Kedokteran, Universitas Malahayati, Lampung
}

\section{Artikel Info :}

Received 20 Juli 2021

Accepted 8 Agustus 2021

Available online 31 Agustus 2021

Editor: Prayudhy Yushananta

Keyword:

DHF, climate, temperature, humidity, rainfall

\section{Kata Kunci :}

DBD, iklim, suhu, kelembaban, curah hujan

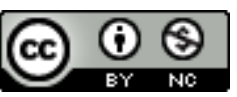

Ruwa Jurai: Jurnal Kesehatan Lingkungan is licensed under a Creative Commons AttributionNonCommercial 4.0 International License.

\begin{abstract}
Dengue hemorrhagic fever (DHF) case in Bandar Lampung City shows an increasing trend of cases. In 2014, the number of cases was 389 cases; by the end of 2018, it had increased to 1,114 cases. Climatic factors are thought to have contributed to the increase in cases. This study aims to determine the relationship between climate factors and the number of dengue cases in 20152019. The study used secondary data with a cross-sectional design. Data were obtained from the Bandar Lampung City Health Office and the Meteorology, Climatology, and Geophysics Agency (BMKG). Univariate analysis with Mean, Median, Minimum-Maximum. The Kolmogorov-Smirnov test was carried out to determine the normality of the data, followed by bivariate analysis with Pearson Correlation and Spearman's Rank. Multivariate analysis was performed with Linear Regression by considering the regression assumption. The study found that more dengue cases were in January, February, March. A negative correlation was shown between temperature and the incidence of DHF ( $r=-0.274$; $p$-value $=0.038)$, and a positive correlation with humidity $(r=0.390 ; p$-value $=0.002)$, and rainfall $(r=0.370 ; p$-value $=0.005)$. Air humidity and rainfall affect the number of dengue cases, respectively $33.0 \%$ and $30.5 \%$. The results of this study have provided evidence of a relationship between climate factors and cases of DHF. It is hoped that this can be an input for the prevention and control of dengue fever.
\end{abstract}

Kasus Demam berdarah dengue (DBD) di Kota Bandar Lampung menunjukkan trend yang terus meningkat. Pada tahun 2014 tercatat sebanyak 389 kasus, pada akhir tahun 2018 meningkat menjadi 1.114 kasus. Faktor iklim diduga berkontribusi terhadap peningkatan kasus. Penelitian bertujuan mengetahui hubungan faktor iklim dengan jumlah kasus DBD pada tahun 2015-2019. Penelitian menggunakan data sekunder dengan rancangan cross sectional. Data diperoleh dari Dinas Kesehatan Kota Bandar Lampung dan Badan Metereologi Klimatologi dan Geofisika (BMKG). Analisis univariat dengan Mean, Median, Minimum-Maximum. Uji Kolomogorovsmirnov dilakukan untuk mengetahui normalitas data, dilanjutkan analisis bivariate dengan Pearson Correlation dan Spearman's Rank. Analisis multivariat dilakukan dengan Regresi Linier dengan mempertimbangkan asumsi regresi. Penelitian mendapatkan bahwa kasus DBD lebih banyak pada bulan Januari, Februari, Maret. Korelasi negatif ditunjukkan antara suhu dengan kejadian DBD ( $r=-0,274 ; p$-value $=0,038)$, dan korelasi positif pada kelembaban $(r=0,390 ; p$ value $=0,002)$, dan curah hujan $(r=0,370 ; p$-value $=0,005)$. Kelembaban udara dan curah hujan memberikan pengaruh terhadap jumlah kasus DBD, masing-masing sebesar 33,0\% dan 30,5\%. Hasil penelitian ini telah memberikan bukti adanya hubungan faktor iklim dengan kasus DBD. Diharapkan dapat menjadi masukan untuk pencegahan dan penanggulangan DBD.

\footnotetext{
* Corresponding author: Gilang Fitra Dininta

Jl. Pramuka No.27, Kemiling Permai, Kec. Kemiling, Kota Bandar Lampung, Lampung 35152.

Email:gilangkousuke@gmail.com
}

\section{PENDAHULUAN}

Demam berdarah dengue (DBD) masih menjadi masalah kesehatan yang penting karena menyebabkan kesakitan dan kematian yang tinggi (Bhatt et al., 2013; Brady et al., 2012; Lloyd, 2003; World Health Organization, 1997, 2011, 2021). Di Indonesia, kasus DBD pertama kali terjadi di Surabaya pada tahun 1968, dan sejak 
itu menjadi negara tertinggi kasus DBD di Asia Tenggara (Karyanti et al., 2014; Kemenkes, 2010; Yushananta, 2021; Yushananta, Setiawan, \& Tugiyono, 2020).

Di Provinsi Lampung, kejadian DBD di (Incident Rate per 100,000 penduduk) pada tahun 2017 sebesar 35,68, melebihi rata-rata nasional, yaitu sebesar 26,12 (Dinas Kesehatan Provinsi Lampung, 2018). Situasi DBD di Kota Bandar Lampung juga menunjukkan trend kasus yang meningkat. Data Dinas Kesehatan Kota Bandar Lampung menyebutkan bahwa jumlah kasus pada tahun 2014 sebanyak 389 kasus $(I R=40,49)$, meningkat menjadi $591 \quad(I R=60,35)$ pada tahun 2015. Pada tahun 2016, jumlah kasus meningkat menjadi 1.172 kasus $(I R=117,47)$, dan hingga akhir tahun 2018 sebanyak 1.114 kasus (IR 107,76) (Dinas Kesehatan Kota Bandar Lampung, 2019). Laporan Rusli dan Yushananta (2020) menyebutkan bahwa rata-rata kejadian DBD di Kota Bandar Lampung tahun 2007-2017 sebesar 103,97 (35,30-230,90), jauh melebihi angka provinsi $42,37(16,37-68,44)$ dan nasional $54,21(27,7-78,6)$ pada periode yang sama (Rusli \& Yushananta, 2020).

Penyakit DBD merupakan fenomena kompleks yang tergantung pada tiga faktor yaitu agent (virus), host (manusia), dan lingkungan (faktor abiotik dan biotik). Ketiga faktor tersebut menentukan tingkat endemisitas dari suatu daerah (Lloyd, 2003; World Health Organization, 2011). Beberapa penelitian menyebutkan beberapa variabel yang berkaitan dengan DBD, yaitu: 1) vektor, berkaitan dengan tempat perkembang biakan, kebiasaan menggigit, kepadatan di lingkungan, dan migrasi dari satu tempat ke tempat lain; 3) Host atau pejamu, antaralain terdapatnya penderita di lingkungan/keluarga, mobilisasi dan paparan terhadap nyamuk, usia dan jenis kelamin; dan 4) lingkungan, yaitu suhu, kelembaban, curah hujan, sanitasi dan kepadatan penduduk (Rusli \& Yushananta, 2020; Yushananta, 2021; Yushananta et al., 2020).

Salah satu faktor lingkungan yang berkontribusi terhadap tingginya kejadian DBD adalah iklim, yaitu suhu, curah hujan, dan kelembaban (Brisbois \& Ali, 2010). Faktor iklim berpengaruh terhadap kelimpahan vektor, sehingga penularan penyakit akan meningkat
(Karyanti et al., 2014; Kraemer et al., 2015; Mondrow, 2016; Rusli \& Yushananta, 2020; Rustia, Wispriyono, Susana, \& Luthfiah, 2010; Tosepu, Tantrakarnapa, Nakhapakorn, \& Worakhunpiset, 2018; Tosepu, Tantrakarnapa, Worakhunpiset, \& Nakhapakorn, 2018; Yushananta, 2021; Yushananta et al., 2020).

Iklim akan mempengaruhi kelangsungan hidup, replikasi, perkembangan atau penyebaran virus dengue dan nyamuk, cara dan proses penularan DBD (Li, Lu, Liu, \& Wu, 2018), serta kelimpahan organisme vektor (Karyanti et al., 2014; Tosepu, Tantrakarnapa, Worakhunpiset, et al., 2018). Penelitian lain menyatakan, faktor cuaca berkaitan dengan umur vektor, Exterinsik Incubation Periode (EIP), pola makan, usia kawin (Brady et al., 2014, 2013; Kesetyaningsih, Andarini, Sudarto, \& Pramoedyo, 2018b; Mourya, Yadav, \& Mishra, 2004; Regis et al., 2008; Tang, Rusli, \& Lestari, 2018)

Hubungan iklim dengan DBD telah dilaporkan pada sejumlah hasil penelitian di beberapa kota di Indonesia dengan hasil yang variasi. Penelitian di Kota Kendari dan Kolaka (Sulawesi Tenggara) mendapatkan korelasi positif antara suhu udara dengan kejadian DBD (Tosepu, Tantrakarnapa, Nakhapakorn, et al., 2018; Tosepu, Tantrakarnapa, Worakhunpiset, et al., 2018). Namun, penelitian di Surabaya mendapatkan korelasi negatif (Tang et al., 2018), bahkan di Sleman tidak menunjukkan hubungan bermakna (Kesetyaningsih, Andarini, Sudarto, \& Pramoedyo, 2018a).

Korelasi positif antara curah hujan dan DBD dilaporkan di Kolaka, Surabaya, Denpasar, Pringsewu (Azhar, Marina, \& Anwar, 2017; Tang et al., 2018; Tosepu, Tantrakarnapa, Nakhapakorn, et al., 2018; Tosepu, Tantrakarnapa, Worakhunpiset, et al., 2018; Yushananta \& Ahyanti, 2014; Yushananta et al., 2020). Namun korelasi negatif di Kendari, Sleman, dan Bali (Azhar et al., 2017; Kesetyaningsih et al., 2018a; Tang et al., 2018; Tosepu, Tantrakarnapa, Nakhapakorn, et al., 2018; Tosepu, Tantrakarnapa, Worakhunpiset, et al., 2018). Demikian pula pada kelembaban, menunjukkan korelasi positif (Kesetyaningsih et al., 2018a; Tang et al., 2018; Tosepu, Tantrakarnapa, Worakhunpiset, et al., 2018), dan negatif (Tosepu, Tantrakarnapa, Nakhapakorn, et 
al., 2018), bahkan tidak berhubungan (Azhar et al., 2017).

Selain hasil yang bervariasi, hingga saat ini masih terbatas laporan penelitian tentang hubungan faktor iklim dan DBD, khususnya di Kota Bandar Lampung. Penelitian bertujuan mengetahui hubungan faktor iklim dan pergerakan kasus DBD di Kota Bandar Lampung pada rentang tahun 2015-2019. Pemahaman yang lebih baik tentang trend penularan DBD akan membantu dalam menentukan strategi pengendalian vektor yang lebih efektif dan berkelanjutan.

\section{METODE}

Penelitian obsevasional menggunakan rancangan cross sectional. Data kasus DBD bersumber dari data bulanan Dinas Kesehatan Kota Bandar Lampung, periode 1 Januari 2015 sampai dengan 31 Desember 2019. Data faktor iklim dari Badan Meteorologi, Klimatologi dan Geofisika (BMKG) yang diperoleh secara online (online website: https://dataonline.bmkg.go.id/), meliputi suhu, kelembapan dan curah hujan. Data harian iklim dari BMKG dikonversi menjadi rata-rata bulanan, sehingga jumlah data pada setiap variabel menjadi sama, sebanyak 60 data.
Data dianalisis menggunakan perangkat statistik dan dilakukan secara bertahap. Analisis univariat menggambarkan frekwensi dan distribusi setiap variabel penelitian menggunakan Mean, Median, dan MinimumMaximum. Dilakukan juga uji normalitas data menggunakan Kolmogorov-Smirnov, sebagai dasar menentukan teknik analisis pada tahap berikutnya.

Analisis bivariat menggunakan Pearson Correlation dan Spearman rank Correlation, sesuai normalitas data. Uji korelasi antara kasus DBD dan faktor iklim dilakukan pada setiap tahun pengamatan $(n=12)$, dan data gabungan $(n=60)$. Analisis multivariat dilakukan dengan Multiple Linier Regression. Kelayakan model memperhitungkan asumsi Multivariat normality, Liniarity, Existency, Homoscedascity, Independency, dan Colinearity.

\section{HASIL}

\section{Gambaran Variabel Penelitian}

Pada Tabel 1 terlihat, rata-rata jumlah kasus DBD setiap bulannya sebanyak 83,4 kasus (9269), suhu udara $28,3^{\circ} \mathrm{C}(27,1-29,4)$, kelembaban udara $81,1 \%(76,0-86,3)$, dan curah hujan $8,9 \mathrm{~mm}$ $(1,7-24,1)$.

Tabel 1. Gambaran variabel penelitian (2015-2019)

\begin{tabular}{llllll}
\hline Variabel & $\mathrm{n}$ (Bulan) & Mean & Median & Minimum & Maximum \\
\hline DBD (kasus) & 60 & 83,4 & 75,0 & 9,0 & 261,0 \\
Suhu (Celcius) & 60 & 28,3 & 28,3 & 27,1 & 29,4 \\
Kelembaban (\%) & 60 & 81,1 & 81,3 & 76,0 & 86,3 \\
Curah hujan (mm) & 60 & 8,9 & 8,0 & 1,7 & 24,1 \\
\hline
\end{tabular}

Berdasarkan jumlah kasus bulanan (Gambar 1), kasus tertinggi pada bulan Februari 2019 (261 kasus), dan terendah pada bulan September 2015 (9 kasus). Secara umum terlihat bahwa pada setiap tahunnya, jumlah kasus tinggi pada bulan Januari, Februari, Maret; dan rendah pada bulan September, Oktober, November, Desember. Pada Tabel 2 terlihat bahwa total kasus DBD di Kota Bandar Lampung tahun 20152019 sebanyak 5.002 kasus. Tertinggi pada tahun 2019 (1.198 kasus) dan terendah tahun 2015 (594 kasus).

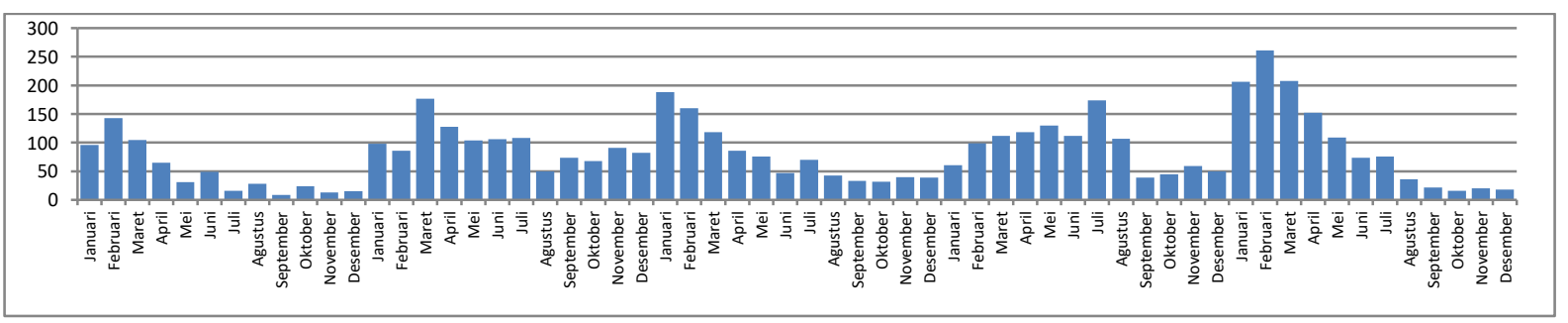

Gambar 1. Jumlah kasus DBD berdasarkan bulan (2015-2019) 
Rata-rata suhu udara (Tabel 2) sebesar $28,3^{\circ} \mathrm{C}$, tertinggi pada tahun $2016\left(28,6^{\circ} \mathrm{C}\right)$, dan terendah tahun $2015\left(28,1^{\circ} \mathrm{C}\right)$. Pada Gambar 2a terlihat bahwa suhu udara lebih rendah pada awal tahun (Januari, Februari, Maret), dan tinggi pada bulan September, Oktober, November.

Hasil penelitian juga mendapatkan bahwa rata-rata kelembaban udara sebesar $81,1 \%$, tertinggi pada tahun 2017 (81,9\%), dan terendah tahun 2015 (80,3\%). Pada setiap tahunnya (Gambar 2b), kelembaban udara cenderung lebih tinggi pada bulan Maret, April, Mei. Pada bulan Agustus, September, Oktober, kelembaban udara cenderung lebih rendah.

Curah hujan rata-rata pada periode tahun 2015-2019 (Tabel 2) sebesar 8,9 mm, tertinggi pada tahun $2019(11,8 \mathrm{~mm})$, dan terendah pada tahun 2017 (7,0 mm). Walaupun tidak menetap, curah hujan lebih banyak pada bulan Desember, Januari, dan Ferbruari; dan lebih sedikit pada Juni dan Juli (Gambar 2c).

Tabel 2. Gambaran variabel penelitian berdasarkan tahun (2015-2019)

\begin{tabular}{llllll}
\hline \multirow{2}{*}{ Tahun } & \multirow{2}{*}{$\mathrm{N}$ (Bulan) } & \multirow{2}{*}{ Kasus } & Mean & & \\
\cline { 4 - 6 } & & & Suhu & Kelembaban & Curah Hujan \\
\hline 2015 & 12 & 594 & 28,1 & 80,3 & 8,4 \\
2016 & 12 & 1.172 & 28,6 & 81,3 & 8,1 \\
2017 & 12 & 932 & 28,2 & 81,9 & 7,0 \\
2018 & 12 & 1.106 & 28,2 & 81,7 & 9,2 \\
2019 & 12 & 1.198 & 28,4 & 80,5 & 11,8 \\
\hline$(2015-2019)$ & 60 & 5.002 & 28,3 & 81,1 & 8,9 \\
\hline
\end{tabular}

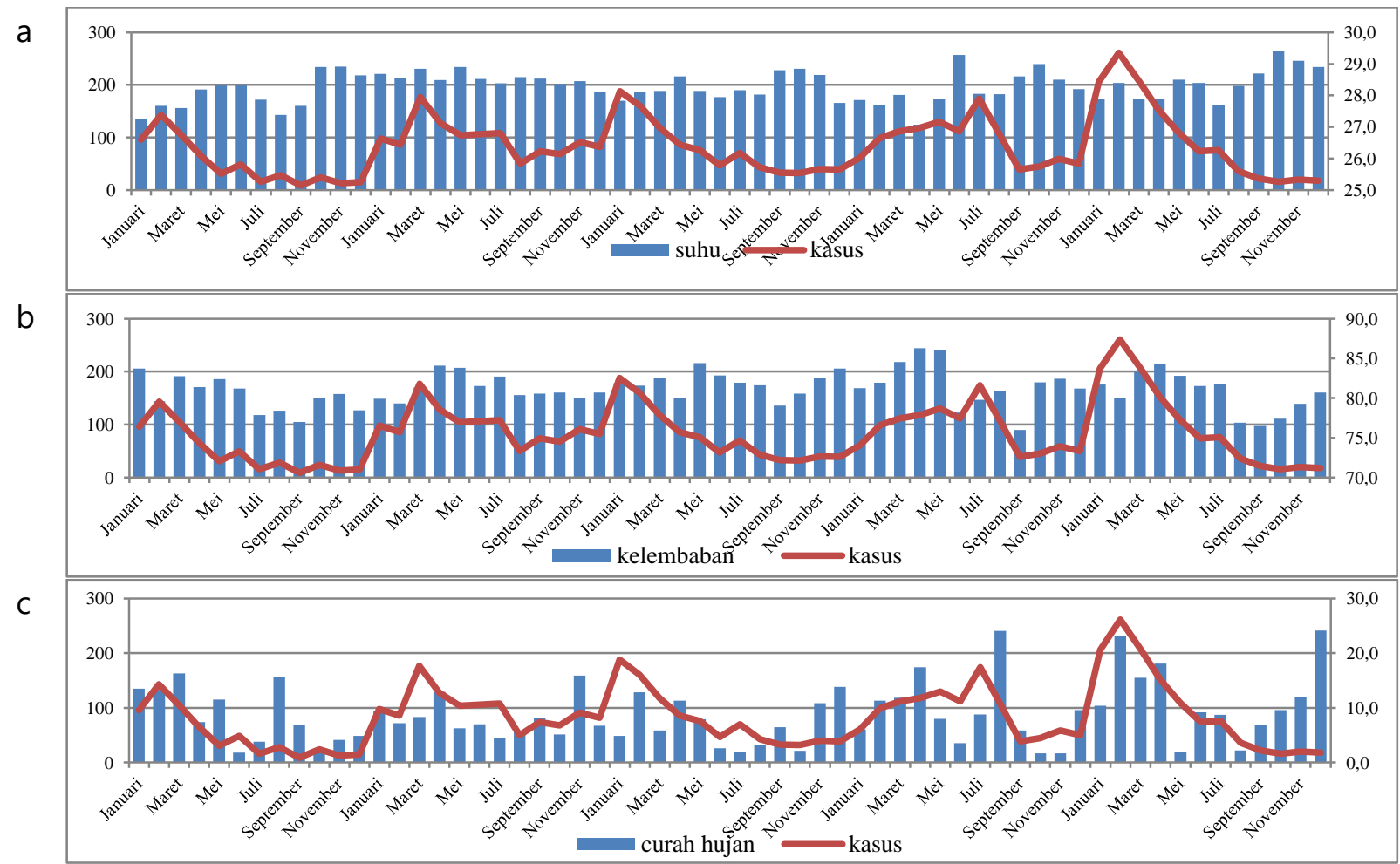

Gambar 2. Trend Kasus DBD dan suhu (a), kelembaban (b), curah hujan (c) di Kota Bandar Lampung tahun 2015-2019

Uji Kolmogorov-Smirnov untuk mengetahui distribusi data setiap variabel penelitian, baik data tahunan $(n=12)$, maupun gabungan $(n=60)$. Hasil penelitian (Tabel 3) mendapatkan bahwa data tidak terdistribusi normal hanya pada kasus DBD tahun 2015, sisanya menunjukkan distribusi normal ( $p$ value $>0,05)$. Pada data gabungan $(n=60)$, keseluruhan data terdistribusi normal, baik jumlah kasus maupun faktor iklim. 
Tabel 3. Uji normalitas data menggunakan Kolmogorov-Smirnov pada $\mathrm{CL}=95 \%$

\begin{tabular}{|c|c|c|c|c|c|}
\hline \multirow{2}{*}{ Tahun } & \multirow{2}{*}{$\mathrm{N}$ (Bulan) } & \multicolumn{4}{|c|}{$p$-value } \\
\hline & & Kasus & Suhu & Kelembaban & Curah Hujan \\
\hline 2015 & 12 & 0,041 & $0,200^{*}$ & $0,200^{*}$ & $0,200^{*}$ \\
\hline 2016 & 12 & $0,158^{*}$ & $0,200^{*}$ & $0,090^{*}$ & $0,089^{*}$ \\
\hline 2017 & 12 & $0,106^{*}$ & $0,083^{*}$ & $0,200^{*}$ & $0,200^{*}$ \\
\hline 2018 & 12 & $0,200^{*}$ & $0,200^{*}$ & $0,200^{*}$ & $0200^{*}$ \\
\hline 2019 & 12 & $0,200^{*}$ & $0,200^{*}$ & $0,200^{*}$ & $0,200^{*}$ \\
\hline$(2015-2019)$ & 60 & $0,081^{*}$ & $0,200^{*}$ & $0,200^{*}$ & $0,200^{*}$ \\
\hline
\end{tabular}

\section{Hubungan Kasus DBD dan Faktor Iklim}

Pada Tabel $4(n=60)$ terlihat bahwa kasus DBD berkorelasi negatif dengan suhu udara, dengan tingkat keeratan hubungan tingkat sedang $(r=0,274 ; \quad p$-value $=0,034)$. Semakin rendah suhu udara, maka semakin tinggi jumlah kasus. Kelembaban udara secara signifikan menunjukkan korelasi positif dengan jumlah kasus DBD, dengan keeratan hubungannya pada tingkat sedang $(r=0,390 ; \quad p$-value $=0,002)$. Tingginya kelembaban udara diikuti dengan meningkatnya jumlah kasus. Demikian pula pada curah hujan, juga menunjukkan korelasi positif tingkat sedang dengan jumlah kasus DBD $(r=0,370 ; p$-value $=0,004)$. Tingginya curah hujan diikuti dengan meningkatnya jumlah kasus DBD.

Berdasarkan data pada masing-masing tahun $(n=12)$, hubungan faktor iklim dan kasus DBD hanya terlihat pada tahun 2015 dan 2019. Pada tahun 2015, jumlah kasus DBD berkorelasi positif dengan kelembaban udara $(r=0,655 ; \quad p$ value $=0,021)$. Sedangkan pada tahun 2019, korelasi negatif yang kuat ditunjukkan antara suhu udara dengan jumlah kasus $(r=0,618 ; p$ value $=0,032$ ).

Tabel 4. Hasil analisis korelasi jumlah kasus DBD dan faktor iklim

\begin{tabular}{lllllllll}
\hline \multirow{2}{*}{ Year } & \multirow{2}{*}{$\mathrm{n}$ (Bulan) } & \multicolumn{2}{l}{ Suhu } & \multicolumn{2}{l}{ Kelembaban } & \multicolumn{2}{c}{ Curah Hujan } & \multirow{2}{*}{ Correlation Test } \\
\cline { 3 - 7 } & & $\mathrm{r}$ & P-Value & $\mathrm{r}$ & P-Value & $\mathrm{r}$ & P-Value & \\
\hline 2015 & 12 & $-0,482$ & 0,113 & $0,655^{*}$ & 0,021 & 0,538 & 0,071 & Spearman's rank \\
2016 & 12 & 0,467 & 0,125 & 0,432 & 0,161 & 0,237 & 0,458 & Pearson Corrl \\
2017 & 12 & $-0,433$ & 0,160 & 0,064 & 0,844 & 0,152 & 0,638 & Pearson Corrl \\
2018 & 12 & $-0,359$ & 0,252 & 0,296 & 0,349 & 0,395 & 0,204 & Pearson Corrl \\
2019 & 12 &,$- 618^{*}$ & 0,032 & 0,569 & 0,054 & 0,382 & 0,221 & Pearson Corrl \\
\hline 2015-2019 & 60 & $-0,274^{*}$ & 0,034 & $0,390^{*}$ & 0,002 & $0,370^{*}$ & 0,004 & Pearson Corrl \\
\hline * signifikan & & & & & & & &
\end{tabular}

Tabel 5 menunjukkan bahwa faktor iklim yang berhubungan dengan kasus DBD di Kota Bandar Lampung adalah kelembaban dan curah hujan. Masing-masing variabel memberikan pengaruh sebesar 33,0\% dan 30,5\%. Berdasarkan nilai koefisien determinasi ( $R$ square), model mampu menjelaskan hubungan faktor iklim dengan kasus DBD sebesar $24,2 \%$, sisanya oleh variabel lain yang tidak masuk dalam penelitian. Penilaian asumsi regresi juga telah terpenuhi, yaitu asumsi Liniarity (ANOVA=0,000), Existency (Mean Residual $=0,000$ ), Independency (Durbin Watson=0,900), Colinearity (VIF kelembaban $=1,04$; curah hujan $=1,04$ ), Multivariat normality dan Homoscedascity (Gambar 4).

Tabel 5. Hasil analisis Multivariat

\begin{tabular}{lllllll}
\hline & $\mathrm{B}$ & $\mathrm{SE}$ & $\mathrm{t}$ & Sig. & Beta & $\mathrm{R}^{2}$ \\
\hline Contanta & $-617,153$ & 238,227 & $-2,591$ & 0,012 & & \\
Kelembaban udara & 8,298 & 2,958 & 2,805 & 0,007 & 0,330 & 0,242 \\
Curah hujan & 3,071 & 1,184 & 2,593 & 0,012 & 0,305 & \\
\hline
\end{tabular}




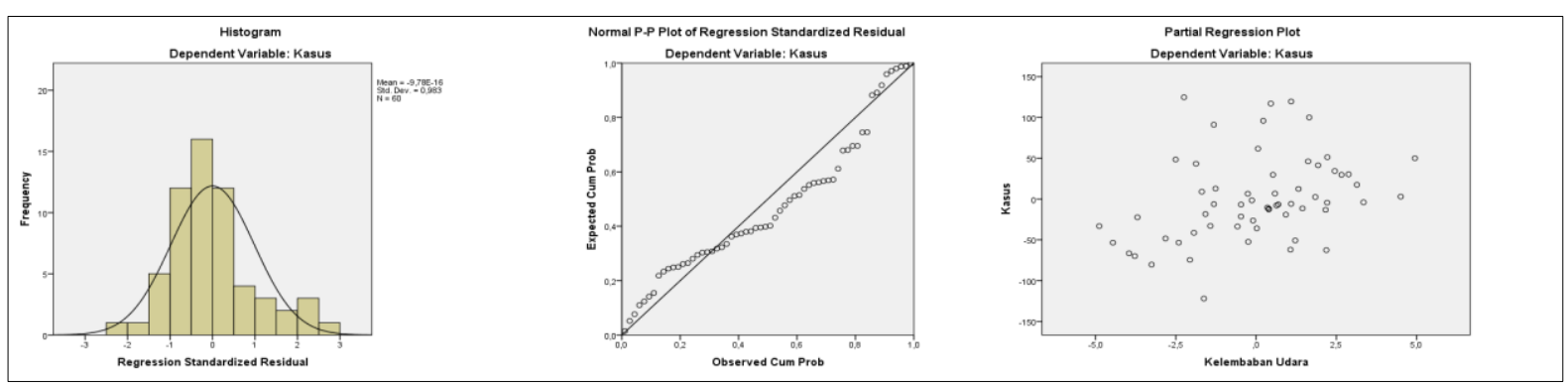

Gambar 3. Histogram of residual (a), Normal P-P Plot Regression Standardize Residual (b), Scater Plot Residual

\section{PEMBAHASAN}

Hasil penelitian menunjukkan bahwa kasus DBD dilaporkan selalu ada pada setiap bulannya, menunjukkan bahwa penyakit telah bersifat endemik. Secara umum, pergerakan kasus dimulai pada bulan November, dan mencapai puncaknya pada setiap awal tahun berikutnya. Penelitian menemukan bahwa kasus DBD lebih tinggi pada bulan Januari, Februari, Maret; dan rendah pada bulan September, Oktober, November, Desember.

Rata-rata suhu udara pada tahun 2015-2019 sebesar $28,3^{\circ} \mathrm{C}$, tertinggi pada tahun 2016 $\left(28,5^{\circ} \mathrm{C}\right)$ dan terendah tahun $2015\left(28,1^{\circ} \mathrm{C}\right)$. Berdasarkan distribusi bulanan, secara umum suhu tinggi pada akhir tahun (September, Oktober, November), dan rendah pada awal tahun (Januari, Februari, Maret). Jika dibandingkan dengan kasus bulanan, maka kasus DBD lebih banyak pada bulan dengan suhu udara yang rendah. Hasil analisis statistik menunjukkan korelasi negatif antara suhu udara, dengan tingkat keeratan hubungan tingkat sedang $(r=0,274 ; \quad p$-value $=0,034)$. Semakin rendah suhu udara, maka semakin tinggi jumlah kasus DBD.

Hasil ini sejalan dengan penelitian yang dilakukan di Yogyakarta yang mendapatkan hubungan signifikan antara suhu udara dengan jumlah kasus DBD (Ayumi, Iravati, \& Umniyati, 2016). Hasil yang sama juga dilaporkan pada penelitian di Surabaya mendapatkan korelasi negatif (Tang et al., 2018).

Suhu berkaitan dengan perkembangan nyamuk Ae.aegypti. Suhu ideal pertumbuhan nyamuk Ae.aegypti adalah $20-30^{\circ} \mathrm{C}$ (Lloyd, 2003; World Health Organization, 2003). Menurut Sigit et al. (2006), telur Ae.aegypti yang diletakkan di air akan menetas selama 1-3 hari pada suhu $30^{\circ} \mathrm{C}$, pada fase pupa dibutuhkan $2-3$ hari pada suhu $20-30^{\circ} \mathrm{C}$.

Suhu udara juga berpengaruh pada masa inkubasi ekstrinsik (EIP), yaitu periode antara saat nyamuk menyerap darah yang mengandung virus dan benar-benar menjadi infeksius. Pada temperatur yang rendah, EIP menjadi lebih lama dan kemungkinan nyamuk bertahan cukup lama untuk menularkan virus (Brady et al., 2014, 2013; Kesetyaningsih et al., 2018b; Mourya et al., 2004; Tang et al., 2018). EIP adalah fungsi suhu non-linier sehingga perubahan suhu yang kecil sekalipun dapat menyebabkan perubahan dinamika transmisi (Focks, Daniels, Haile, \& Keesling, 1995; Morin, Comrie, \& Ernst, 2013).

Penelitian mendapatkan bahwa rata-rata kelembaban udara sebesar $81,1 \%$, tertinggi pada tahun 2017 (81,9\%) dan terendah tahun 2015 (80,3\%). Berdasarkan distribusi setiap bulannya, kelembaban udara cenderung lebih tinggi pada bulan Maret, April, Mei. Pada bulan Agustus, September, Oktober, kelembaban udara cenderung lebih rendah.

Hasil analisis statistik korelasi positif antara kelembaban dengan kasus DBD $(r=0,390 ; p$ value $=0,002$ ). Semakin tinggi kelembaban udara, maka semakin tinggi jumlah kasus DBD. Hasil ini sejalan dengan penelitian yang di lakukan di Surabaya yang menyatakan hubungan antara kelembaban dengan kejadian DBD (Paramita \& Mukono, 2018). Korelasi positif juga dilaporkan di Sleman, Bali, dan Kolaka (Kesetyaningsih et al., 2018a; Tang et al., 2018; Tosepu, Tantrakarnapa, Worakhunpiset, et al., 2018)

Kelembaban berpengaruh pada pola makan, usia kawin, penyebaran dan lama hidup Ae.aegypti, serta mempercepat replikasi virus 
(Brady et al., 2014, 2013; Negev et al., 2015; Regis et al., 2008; Yushananta et al., 2020). Pada musim penghujan dengan kelembaban tinggi, vektor betina dapat bertahan dua kali lipat lebih banyak sehingga dapat menghasilkan lebih banyak telur (Regis et al., 2008; Yushananta et al., 2020).

Hasil penelitian juga mendapatkan bahwa kelembaban udara memberikan pengaruh sebesar 33,0\% terhadap jumlah kasus DBD. Hasil ini menunjukkan pentingnya pemahaman tentang iklim dalam sistem surveillance dan pengendalian DBD. Faktor iklim menjadi salah satu variabel dalam memprediksi peningkatan jumlah kasus DBD.

Pada curah hujan, penelitian mendapatkan nilai rata-rata sebesar $8,9 \mathrm{~mm}$, tertinggi pada tahun 2019 (11,8 mm), dan terendah tahun 2017 (7,0 mm). Berdasarkan distribusi bulan, maka secara curah hujan lebih banyak pada bulan Desember, Januari, dan Ferbruari; dan lebih sedikit pada Juni dan Juli (Gambar 2c).

Hasil uji hubungan menunjukan korelasi positif tingkat sedang dengan jumlah kasus DBD $(r=0,370 ; p$-value $=0,004)$. Tingginya curah hujan diikuti dengan meningkatnya jumlah kasus DBD. Pada Tabel 5, diketahui bahwa pengaruh curah hujan terhadap peningkatan kasus DBD sebesar $30,5 \%$. Hasil penelitian dengan korelasi positif juga dilaporkan di Kolaka, Surabaya, Denpasar, Pringsewu (Azhar et al., 2017; Rusli \& Yushananta, 2020; Tang et al., 2018; Tosepu, Tantrakarnapa, Nakhapakorn, et al., 2018; Tosepu, Tantrakarnapa, Worakhunpiset, et al., 2018; Yushananta, 2021; Yushananta et al., 2020).

Hubungan curah hujan dengan kasus DBD melalui kelimpahan dan distribusi vektor (Gubler, 2013; Lloyd, 2003; World Health Organization, 1997, 2011). Pada musim penghujan, air akan mengisi tempat-tempat yang dapat menampung air (alami atau buatan) sehingga berpotensi menjadi breading places (Lloyd, 2003; World Health Organization, 2011, 2014; Yushananta \& Ahyanti, 2014). Selain meningkatkan jumlah tempat perindukan, telur nyamuk yang sebelumnya sudah ada di wadah-wadah mengering, akan segera menetas menjadi jentik setelah terendam air dalam 1-2 hari (Lloyd, 2003; World Health Organization, 1997, 2011).
Faktor iklim tidak berdiri sendiri, tetapi saling mempengaruhi satu sama lainnya. Penelitian ini mendapatkan bahwa kelembaban dan curah hujan bersama-sama memberikan pengaruh signifikan terhadap peningkatan kasus DBD. Tingginya curah hujan akan meningkatkan kelembaban. Dalam penyebaran dengue, kondisi ini akan meningkatkan jumlah breading places, kecepatan replikasi virus, lama hidup dan penyebaran vektor, serta memperpendek EIP (Brady et al., 2014, 2013; Kesetyaningsih et al., 2018b; Mourya et al., 2004; Regis et al., 2008; Tang et al., 2018). Sehingga, pemberantasan vektor melalui pengelolaan lingkungan menjadi upaya pengendalian DBD yang efektif. Selama obat dan vaksin belum ditemukan, satu-satunya cara untuk menanggulangi DBD adalah melalui pengelolaan lingkungan (Lloyd, 2003; World Health Organization, 2011, 2021).

\section{SIMPULAN}

Hasil penelitian mendapatkan bahwa kasus DBD lebih banyak pada awal tahun (Januari, Februari, Maret), bersamaan dengan tingginya curah hujan $(r=0,370 ; p$-value $=0,005)$ dan kelembaban udara $(r=0,390 ; p$-value $=0,002)$, serta rendahnya suhu udara $(r=-0,274 ; p$ value $=0,038$ ). Kelembaban udara dan curah hujan memberikan pengaruh terhadap jumlah kasus DBD, masing-masing sebesar 33,0\% dan $30,5 \%$. Penelitian ini telah menunjukkan bahwa faktor iklim merupakan faktor penting dalam menentukan kejadian DBD di Kota Bandar Lampung. Untuk itu, otoritas kesehatan perlu mengembangkan sistim surveilans berbasis iklim dalam pengamatan penyakit DBD, melakukan penguatan pengelolaan lingkungan berbasis masyarakat, serta penelitian komprehensif.

\section{UCAPAN TERIMAKASIH}

Ucapan terima kasih disampaikan kepada Dinas Kesehatan Kota Bandar Lampung, Badan Meteorologi, Klimatologi dan Geofisika (BMKG).

\section{DAFTAR PUSTAKA}

Ayumi, F., Iravati, S., \& Umniyati, S. R. (2016). Hubungan iklim dan kondisi lingkungan fisik rumah terhadap insidensi demam berdarah dengue di beberapa zona musim di Daerah Istimewa Yogyakarta (Studi kasus di Kecamatan 
Kasihan, Kabupaten Bantul, Yogyakarta). Berita Kedokteran Masyarakat, 32(12), 455. https://doi.org/10.22146/bkm.8790

Azhar, K., Marina, R., \& Anwar, A. (2017). A prediction model of Dengue incidence using climate variability in Denpasar city. Health Science Journal of Indonesia, 8(2), 68-73. https://doi.org/10.22435/hsji.v8i2.6952.68-73

Bhatt, S., Gething, P. W., Brady, O. J., Messina, J. P., Farlow, A. W., Moyes, C. L., ... Hay, S. I. (2013). The global distribution and burden of dengue. Nature, 496(7446), 504-507. https://doi.org/10.1038/nature12060

Brady, O. J., Gething, P. W., Bhatt, S., Messina, J. P., Brownstein, J. S., Hoen, A. G., ... Hay, S. I. (2012). Refining the Global Spatial Limits of Dengue Virus Transmission by Evidence-Based Consensus. PLoS Neglected Tropical Diseases, 6(8), e1760. https://doi.org/10.1371/journal.pntd.0001760

Brady, O. J., Golding, N., Pigott, D. M., Kraemer, M. U. G., Messina, J. P., Reiner, R. C., ... Hay, S. I. (2014). Global temperature constraints on Aedes aegypti and Ae. albopictus persistence and competence for dengue virus transmission. Parasites and Vectors, 7(1), 1-17. https://doi.org/10.1186/1756-3305-7-338

Brady, O. J., Johansson, M. A., Guerra, C. A., Bhatt, S., Golding, N., Pigott, D. M., ... Hay, S. I. (2013). Modelling adult Aedes aegypti and Aedes albopictus survival at different temperatures in laboratory and field settings. Parasites and Vectors, 6(1), 1-12. https://doi.org/10.1186/1756-3305-6-351

Brisbois, B. W., \& Ali, S. H. (2010). Climate change, vector-borne disease and interdisciplinary research: social science perspectives on an environment and health controversy. EcoHealth, 7(4), 425-438.

Dinas Kesehatan Kota Bandar Lampung. (2019). Profil Kesehatan Kota Bandar Lampung Tahun 2018. Bandar Lampung.

Dinas Kesehatan Provinsi Lampung. (2018). Profil Kesehatan Provinsi Lampung Tahun 2017. Bandar Lampung: Dinas Kesehatan Provinsi Lampung.

Focks, D. A., Daniels, E., Haile, D. G., \& Keesling, J. E. (1995). A Simulation Model of the Epidemiology of Urban Dengue Fever: Literature Analysis, Model Development, Preliminary Validation, and Samples of Simulation Results. The American Journal of Tropical Medicine and Hygiene, 53(5), 489-506. https://doi.org/10.4269/ajtmh.1995.53.489 Gubler, D. J. (2013). Prevention and control of Aedes aegypti-borne diseases: Lesson learned from past successes and failures. Asia-Pacific Journal of Molecular Biology and Biotechnology, 19(3), 111-114.

Karyanti, M. R., Uiterwaal, C. S. P. M. P. M., Kusriastuti, R., Hadinegoro, S. R., Rovers, M. M., Heesterbeek, H., ... Bruijning-Verhagen, P. (2014). The changing incidence of Dengue Haemorrhagic Fever in Indonesia: a 45-year registry-based analysis. BMC Infectious Diseases, 14(1), 412. https://doi.org/10.1186/1471-2334$14-412$

Kemenkes. (2010, August). Demam Berdarah Dengue di Indonesia Tahun 1968-2009. Buletin Jendela Epidemiologi, 1-14. Retrieved from https://www.kemkes.go.id/download.php?file=d ownload/pusdatin/buletin/buletin-dbd.pdf

Kesetyaningsih, T. W., Andarini, S., Sudarto, \& Pramoedyo, H. (2018a). Determination of environmental factors affecting dengue incidence in Sleman District, Yogyakarta, Indonesia. African Journal of Infectious Diseases, 12(Special Issue 1), 13-25.

https://doi.org/10.2101/Ajid.12v1S.3

Kesetyaningsih, T. W., Andarini, S., Sudarto, S., \& Pramoedyo, H. (2018b). The minimummaximum weather temperature difference effect on dengue incidence in sleman regency of Yogyakarta, Indonesia. Walailak Journal of Science and Technology, 15(5), 387-396.

Kraemer, M. U. G., Sinka, M. E., Duda, K. A., Mylne, A. Q. N., Shearer, F. M., Barker, C. M., ... Hay, S. I. (2015). The global distribution of the arbovirus vectors Aedes aegypti and Ae. Albopictus. ELife, 4(JUNE2015), 1-18.

https://doi.org/10.7554/eLife.08347

Li, C., Lu, Y., Liu, J., \& Wu, X. (2018). Climate change and dengue fever transmission in China: Evidences and challenges. Science of the Total Environment, 622-623(19), 493-501. https://doi.org/10.1016/j.scitotenv.2017.11.326

Lloyd, L. S. (2003). Best practices for dengue prevention and control in the Americas. Washington DC Camp Dresser and McKee International Environmental Health ....

Mondrow, E. (2016). Climate change and health. Annals of Internal Medicine, 165(10), 745-746. https://doi.org/10.7326/L16-0413

Morin, C. W., Comrie, A. C., \& Ernst, K. (2013). Climate and Dengue Transmission: Evidence and Implications. Environmental Health 
Perspectives, 121(11-12), 1264-1272.

https://doi.org/10.1289/ehp.1306556

Mourya, D. T., Yadav, P., \& Mishra, A. C. (2004).

Effect of temperature stress on immature stages and susceptibility of Aedes aegypti mosquitoes to chikungunya virus. American Journal of Tropical Medicine and Hygiene, 70(4), 346-350.

Negev, M., Paz, S., Clermont, A., Pri-Or, N. G., Shalom, U., Yeger, T., \& Green, M. S. (2015). Impacts of climate change on vector borne diseases in the mediterranean basin implications for preparedness and adaptation policy. International Journal of Environmental Research and Public Health, 12(6), 6745-6770. https://doi.org/10.3390/ijerph120606745

Paramita, R. M., \& Mukono, J. (2018). Hubungan Kelembapan Udara dan Curah Hujan Dengan Kejadian Demam Berdarah Dengue di Puskesmas Gunung Anya 2010-2016. The Indonesian Journal of Public Health, 12(2), 202. https://doi.org/10.20473/ijph.v12i2.2017.202212

Regis, L., Monteiro, A. M., De Melo-Santos, M. A. V., Silveira, J. C., Furtado, A. F., Acioli, R. V., ... De Souza, W. V. (2008). Developing new approaches for detecting and preventing Aedes aegypti population outbreaks: Basis for surveillance, alert and control system. Memorias Do Instituto Oswaldo Cruz, 103(1), 50-59. https://doi.org/10.1590/S007402762008000100008

Rusli, Y., \& Yushananta, P. (2020). Climate variability and dengue hemorrhagic fever in Bandar Lampung, Lampung Province, Indonesia. International Journal of Innovation, Creativity and Change, 13(2), 323-336.

Rustia, H. N., Wispriyono, B., Susana, D., \& Luthfiah, F. N. (2010). Lama Pajanan Organofosfat Terhadap Penurunan Aktivitas Enzim Kolinesterase Dalam Darah Petani Sayuran. Makara Kesehatan, 14(2), 95-101.

Sigit, S. H., Koesharto, F. X., Hadi, U. K., Gunandini, D. J., Soviana, S., Wirawan, I. A., ... Utomo, S. (2006). Hama Pemukiman Indonesia: Pengenalan, Biologi, dan Pengendalian (1st ed.; S. H. Sigit \& U. K. Hadi, eds.). Bogor: Fakultas Kedokteran Hewan, Institut Pertanian Bogar.

Tang, S. C. N., Rusli, M., \& Lestari, P. (2018). Climate Variability and Dengue Hemorrhagic Fever in Surabaya, East Java, Indonesia. Arlangga Unversity, (December). https://doi.org/10.20944/preprints201812.0206. v1

Tosepu, R., Tantrakarnapa, K., Nakhapakorn, K., \& Worakhunpiset, S. (2018). Climate variability and dengue hemorrhagic fever in Southeast Sulawesi Province, Indonesia. Environmental Science and Pollution Research, 25(15), 14944 14952. https://doi.org/10.1007/s11356-0181528-y

Tosepu, R., Tantrakarnapa, K., Worakhunpiset, S., \& Nakhapakorn, K. (2018). Climatic factors influencing dengue hemorrhagic fever in Kolaka district, Indonesia. Environment and Natural Resources Journal, 16(2), 1-10. https://doi.org/10.14456/ennrj.2018.10

World Health Organization. (1997). Dengue Haemorrhagic Fever Diagnosis, Treatment, prevention and Control (second Edi).

World Health Organization. (2003). Comprehensive guidelines for prevention and control of dengue and dengue haemorrhagic fever. In WHO Regional Publication SEARO.

https://doi.org/10.1017/СBO9781107415324.00 4

World Health Organization. (2011). Comprehensive guideline for prevention and control of dengue and dengue haemorrhagic fever.

World Health Organization. (2014). World Health Statistic 2014.

World Health Organization. (2021). Dengue and severe dengue. Retrieved August 3, 2021, from WHO website: https://www.who.int/newsroom/fact-sheets/detail/dengue-and-severedengue

Yushananta, P. (2021). Dengue Hemorrhagic Fever and Its Correlation with The Weather Factor In Bandar Lampung City City: Study From 20092018. Jurnal Aisyah: Jurnal Ilmu Kesehatan, 6(1), 117-126.

Yushananta, P., \& Ahyanti, M. (2014). Pengaruh Faktor Iklim Dan Kepadatan Jentik Ae.Aegypti Terhadap Kejadian DDB. Jurnal Kesehatan Lingkungan, $V(1), 1-10$. https://doi.org/http://dx.doi.org/10.26630/jk.v5i 1.58

Yushananta, P., Setiawan, A., \& Tugiyono, T. (2020). Variasi Iklim dan Dinamika Kasus DBD di Indonesia: Systematic Review. Jurnal Kesehatan, 11(2), 294. https://doi.org/10.26630/jk.v11i2.1696 